\title{
HISTOLOGICAL STUDY OF THE EFFECTS OF CAFFEINE ON THE CARDIAC MUSCLE OF CHICK EMBRYO WITH SPECIAL REFERENCE TO THE MEMBRANE STABILJZING ROLE OF LIDOCAINE
}

\author{
Shahira Youssef, Ashraf Ramzy and Azza S. Soliman \\ Anatomy Department, Faculty of Medicine, Ain Shams University
}

\section{INTRODUCTION}

A wide variety of substances taken into the human body can affect the fetal outcome adversely. Of considerable interest among these substances are caffeine, nicotine and alcohol. Caffeine, in particular, seems to be the most commonly used since it is present in a number of dietry sources for example tea, coffee, cocoa, beverages, chocolate bars and soft drinks (Fredholm et al., 1999). Caffeine has also received recently more attention as a model drug of abuse (Hughes et al., 1998).

A survey of the literature clarified that caffeine could alter fetal development and induce hematomas in the yolk sac as well as dysmorphogenesis in forelimb and hindlimb buds (Iwase et al., 1994). Early exposure to caffeine during pregnancy can also increase the brain excitability (Guillet and Dumham, 1995).

Most studies concerned with the effects of caffeine on the cardiovascular system have concentrated mainly on the physiological effects and to a lesser extent on the gross morphological changes with marked discrepancy and controverted results. Few studies claimed that there was no association between caffeine consumption and the cardiovascular congenital anomalies apart from few hemangiomas (ShaiLinin et al., 1982). On the other hand, Matsuka et al. (1987) noticed that caffeine was a potent inducer of ventricular septal defects. Moreover, Miller et al. (1994) and Miller et al. (1997) stated that there was an accelerated maternal and fetal heart rates with increased fetal aortic peak velocity following caffeine intake.

Up to our knowledge, little data exist about the ultrastructural changes induced by prenatal intake of caffeine. Reviewing the literature revealed that the etiology of the action of caffeine was still obscure, and various theories had been hypothesized. 
It was postulated that the damaging effects of caffeine were attributed either to the release of cytosolic proteins (Harding and Duncan, 1996), or to the release of calcium (Xu and Meissner, 1998; Cavagna et al., 2000).

Recently, it is postulated that the membrane stabilizers can inhibit the release of cytosolic proteins (Harding and Duncan, 1996). Lidocaine, as a membrane stabilizer, is progressively used nowadays in treatment of ventricular arrhythmias and postoperative patients in intensive care units or those who have recent myocardial infarction (Harding and Duncan, 1996).

Accordingly, it was the first aim of the present work to illustrate the myocardial structure after the administration of caffeine using the chick embryo as an experimental model. Furthermore, there was an attempt to estimate the role of lidocaine in abolishing the damaging effects of caffeine by mimicking the role of the cytosolic proteins on the myocardium.

\section{MATERIAL AND METHODS}

Ninety fertilized leghorn eggs were used in the present study. They were divided into three groups, thirty eggs cach. The start of incubation was pointed out as day one.

\section{Group I :}

Twenty five eggs were instilled with three divided doses of caffeine each of which consisted of $1 \mathrm{ml}$ of $0.25 \mathrm{mg} / \mathrm{ml}$ of $0.15 \mathrm{M} \mathrm{NaCl}$. The doses were given on the $5^{\text {th }}, 10^{\text {th }}$ and $15^{\text {th }}$ days of incubation respectively with a total dose of $0.75 \mathrm{mg}$ caffeine. Each dose was assumed to represent about $250 \mathrm{mg}$ of caffeine in a human weighing $70 \mathrm{~kg}$ and that corresponded to an average intake of three cups of coffee per day (Ferdholm et al., 1999). Five eggs were instilled with $1 \mathrm{ml}$ of $0.15 \mathrm{M} \mathrm{NaCl}$ on the same days and their embryos were used as controls for the first group.

\section{Group II :}

Twenty five eggs were instilled with three divided doses of caffeine. Each dose was $1 \mathrm{ml}$ of $0.5 \mathrm{mg} / \mathrm{ml}$ of $0.15 \mathrm{M} \mathrm{NaCl}$. The doses were given on the $5^{\text {th }}, 10^{\text {th }}$ and $15^{\text {th }}$ days of incubation with a total dose of $1.5 \mathrm{mg}$ caffeine. Each dose was assumed to represent $500 \mathrm{mg}$ of caffeine in a human weighing $70 \mathrm{~kg}$ and that corresponded to a high daily consumption (Ferdholm et al., 1999). Five eggs were instilled with 1 
$\mathrm{ml}$ of $0.15 \mathrm{M} \mathrm{NaCl}$ on the same days and their embryos were used as controls for the second group.

\section{Group III :}

Twenty five eggs were instilled with three divided doses of caffeine. Each dose was $1 \mathrm{ml}$ of $0.5 \mathrm{mg} / \mathrm{ml}$ of $0.15 \mathrm{M} \mathrm{NaCl}$ simultaneously with $0.2 \mathrm{ml}$ of Lidocaine $2 \%$ on the $5^{\text {th }}, 10^{\text {th }}$ and $15^{\text {th }}$ days of incubation respectively. Five eggs were instilled with $1.2 \mathrm{ml}$ of $0.15 \mathrm{M} \mathrm{NaCl}$ on the same days and their embryos were used as controls for the third group.

\section{Mode of instillation :}

The eggs were incubated in an electric incubator under adjusted temperature $\left(35^{\circ} \pm 0.5^{\circ} \mathrm{C}\right)$ and proper humidity and were rotated manually on daily basis. On the selected days of instillation, the solutions were deposited slowly and drop-wise into the air space through a manually performed drill at the broad end of the egg. After instillation, the hole was sealed by white cement and the eggs were reincubated (Person, 1983).

\section{Tissue Preparation :}

All eggs were opened on the $20^{\text {th }}$ day and the embryos were extracted. Only viable embryos were selected and their hearts were immediately excised. For light microscopic examinations, specimens were fixed in $10 \%$ formol-saline and processed to paraffin blocks. Sections were cut at 5 um in thickness and stained with haematoxylin and eosin.

Other specimens were cut into small pieces $1 \mathrm{~mm}$ in diameter, fixed in $4 \%$ glutaraldelyde and processed for electron microscopic examination. Semithin sections were stained with toluidine blue, whereas ultrathin sections were stained with uranyl acetate and lead citrate and examined and photographed under Philips 400 TEM.

\section{RESULTS}

\section{The control groups :}

Light microscopic examination of the cardiac muscle of chick embryos of all the control groups showed that the cardiac muscle formed a continuous network of elongated bands of muscle fibers with interposed oval nuclei (Fig. 1). 
The ultrastructural examination revealed that the cardiac muscle fibers were surrounded by distinct sarcolemmal membrane and exhibited a prominent pattern of cross striations (Figs. 2, 3). The Z-lines were the most electron dense bands dividing the myofibrils into sarcomeres. Within the sarcomeres, the A-bands were bisected by broad light $H$-bands which were further bisected by dark M-lines (Figs. 2,3). The sarcomeres were separated by sarcoplasm containing euochromatic nuclei and rows of elongated mitochondria with abundant closely-packed cristea, lace like sarcoplasmic reticulum and few glycogen granules were also seen (Figs. 2, 3, 4). The cell junctions were defined by intercalated discs and the desmosmes appeared in a less frequent manner (Figs. 3, 5).

\section{Group I :}

Light microscopic examination of the cardiac muscle of chick embryos of first group, which received a total dose of $0.75 \mathrm{mg}$ caffeine divided on three successive instillations, showed that the cardiac muscle manifested few focal areas with partial separation of the adjacent cardiac muscle fibers (Fig. 6). Eosinophilic homogeneously-stained patches with adherent nuclei and areas of mononuclear cellular infiltration were frequently encountered (Figs. 6,7).

Ultrastructural examination clarified that the sarcolemmal membrane and the intercalated discs were intact (Figs. 8, 9). The striations of the cardiac muscle were generally preserved, yet few Z-lines wcre distorted and blurred (Fig. 8). Occasionally small localized areas of loss striations were noticed (Fig. 10). The mitochondria displayed various degrees of degeneration. Some mitochondria were swollen and suffered partial or complete loss of cristea (Fig. 11). Others were dense pleomorphic in shape and infiltrated the areas with lost striations (Fig. 10). Glycogen granules were prominent and often formed aggregated rosettes (Fig. 11).

\section{Group II :}

Examination of the cariac muscle of chick embryos of group II, which received a total dose of $1.5 \mathrm{mg}$ caffeine divide on three successive instillations, showed marked distorted arrangement and widening of the adjacent cardiac muscle fibers (Fig. 12). The cardiac muscle exhibited characteristic alteration in shape which could be distinguished either as marked thinning or extreme clumping (Fig. 13). Fatty cellular infiltration and pyknotic nuclei were frequently observed (Fig. 13).

The ultrastructural examinations demonstrated that the cardiac muscle was severely damaged and the myofibrils showed marked disintegration and dissolution 
resulting in wide areas of loss of striations. The intertupted areas were infiltrated by randomly disposed irregular vacuoles, myelin-like figures and dense pleomorphic mitochondria (Fig. 14). Other areas with iess evident loss of striations and öısorganization were infilurated by numerous fat droplets and aggregates of dense mitochon dria (Fig. 15). The sarcolemmal membrane was highly folded and indisinet (Fig. 16). Marked proliferation of sarcoplasmic reticulum was noticed. It exhibited fingerprint appearance with few interposed vacuoles (Fig. 17),

\section{Group III :}

Examination of the cardiac muscle of chick embryos of group III, which received a total dose of $1.5 \mathrm{mg}$ of caffcine associated with $0.6 \mathrm{ml}$ lidocaine on three successive instillations, showed that the cardiac muscle had a prescrved architecture forming a continuous clongated network of muscle fibers (Fig. 18). However, some nuclei were dense, highly basophilic and adherent together (Fig. 18).

The ultrastructurai examinations revealed the integrity of the sarcolemmal membrane, with preservation of intercalated discs (Fig. 19). Although most of the myofibrils exhibited distinct striations, yet areas with loss of striations were still encountered and infiltrated by bizarre vacuoles (Fig. 19). Structural changes were noticed also in the mitochondria in the form of partial loss of cristea (Figs. 19, 20). Large macrophages were observed interposed between the myofibrils, containing numerous prominent lysosomes, mulliple vacuoles and degenerated mitochondria (Fig. 20). 


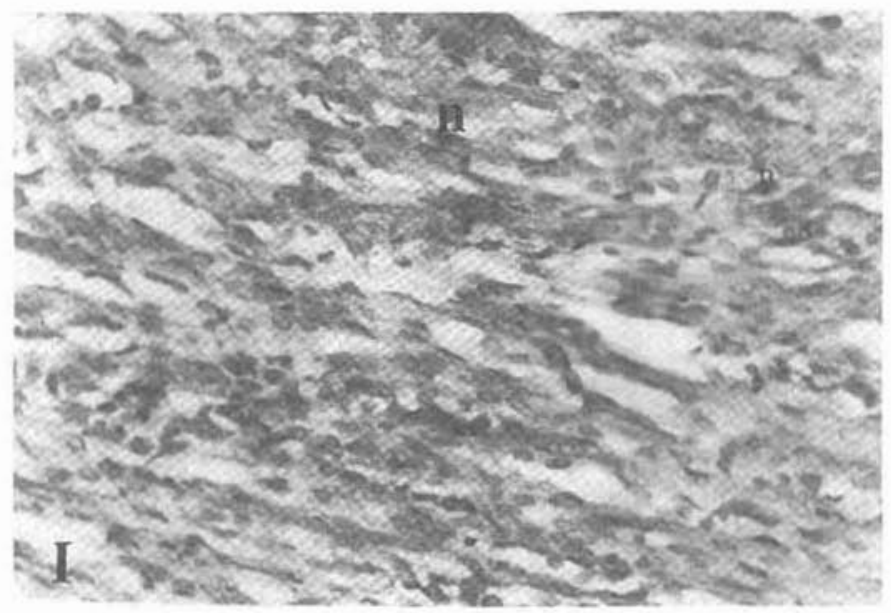

Fig. (1) : A photomicrograph of cardiac muscle of chick embryo of the control group showing a continuous network of elongated bands of muscle fibers and oval nuclei $(\mathbf{n})$.

(Hx. \& E.; $x$ 400)

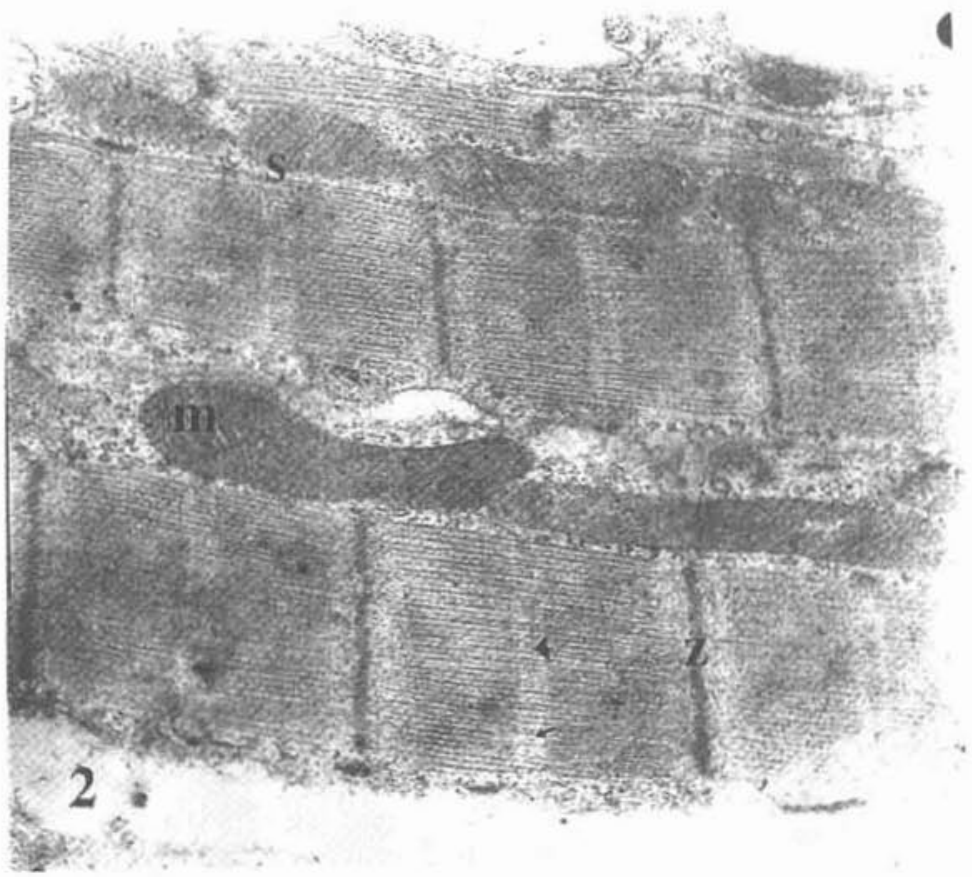

Fig. (2) : An electromicrograph of cardiac muscle of chick embryo of the control group showing sarcolemmal membrane (s) and prominent $\mathrm{Z}$ lines (z), light $\mathrm{H}$ bands $(\uparrow)$ and $\mathrm{M}$ line ( $\mathrm{\omega})$. Notice the elongated mitochondria $(\mathrm{m})$.

(Uranyl acetate \& lead citrate; $x$ 18.000) 


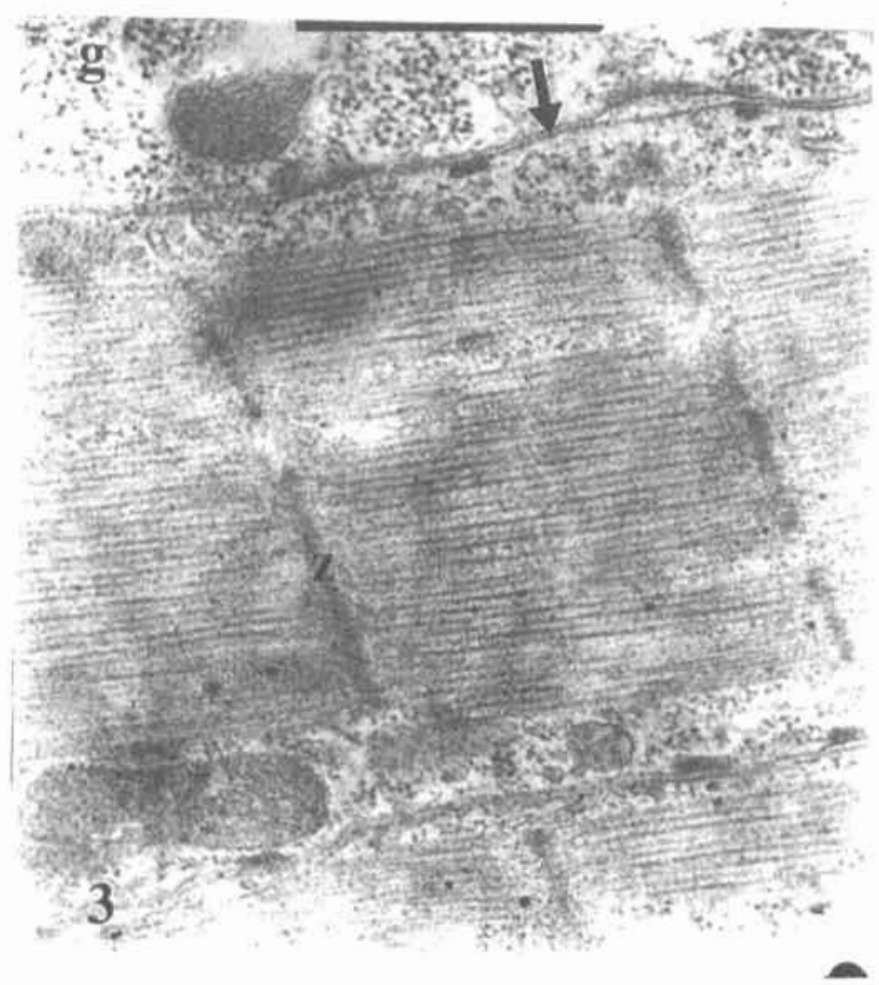

Fig. (3) : An electromicrograph of the cardiac muscle of chick embryo of the control group showing distinct sarcolemmal membrane $(\uparrow)$. Notic the $\mathrm{Z}$ line $(\mathrm{z})$ and the glycogen granules $(\mathrm{g})$.

(Uranyl acetate \& lead citrate; $x$ 27.500) 


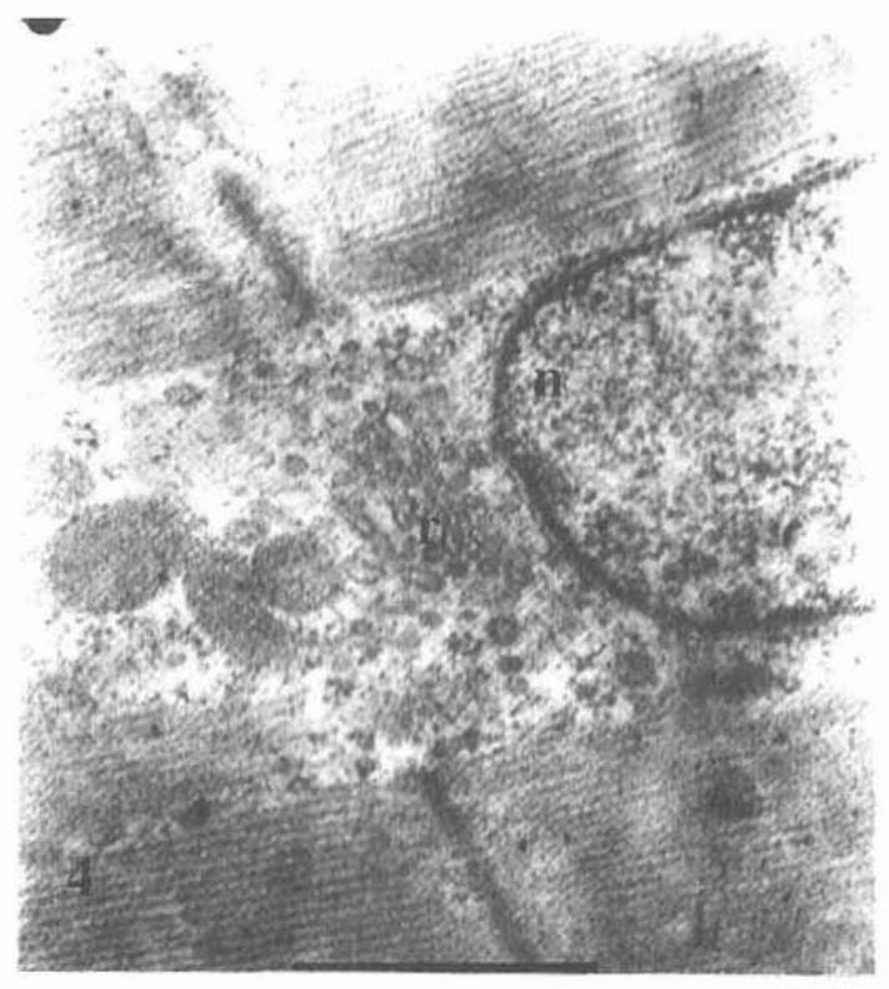

Fig. (4) : An electromicrograph of the cardiac muscle of chick embryo of control group showing the lace-like sarcoplasmic reticulim (r) and euochromatic nucleus (n).

(Uranyl acetate \& lead citrate; x 33.000) 


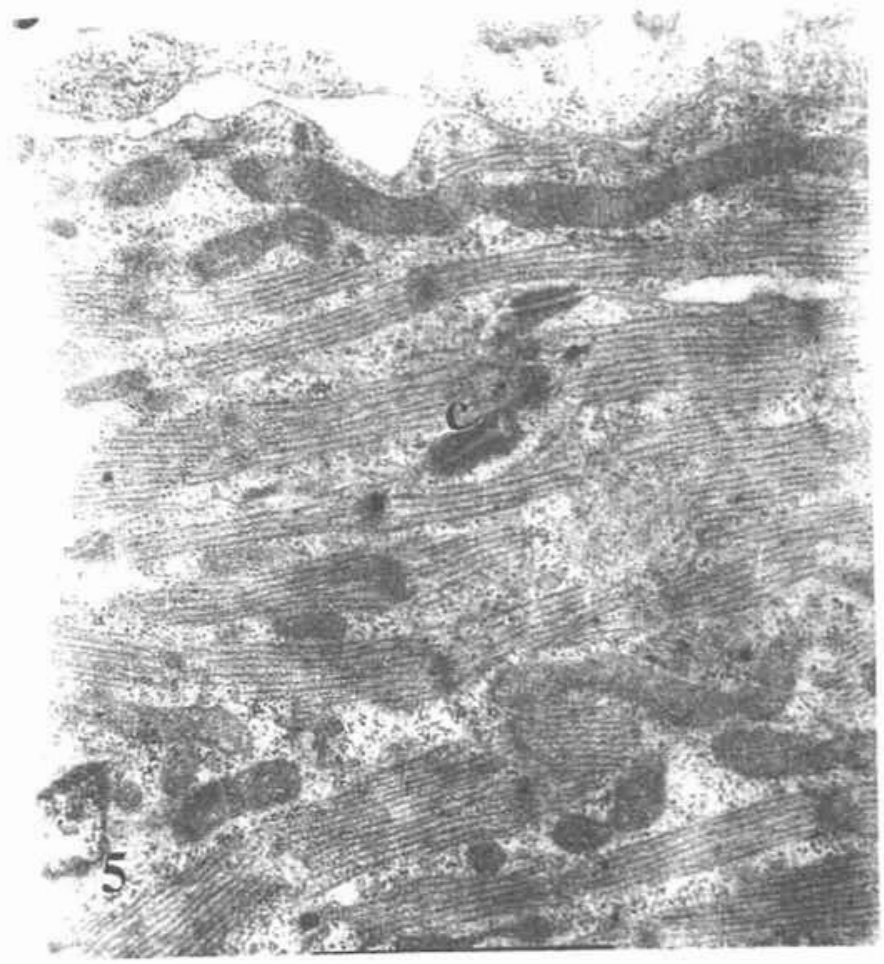

Fig. (5) : An electromicrograph of the cardiac muscle of chick embryo of control group showing the intercalated discs (c).

(Uranyl acetate \& lead citrate; $x$ 18.000) 


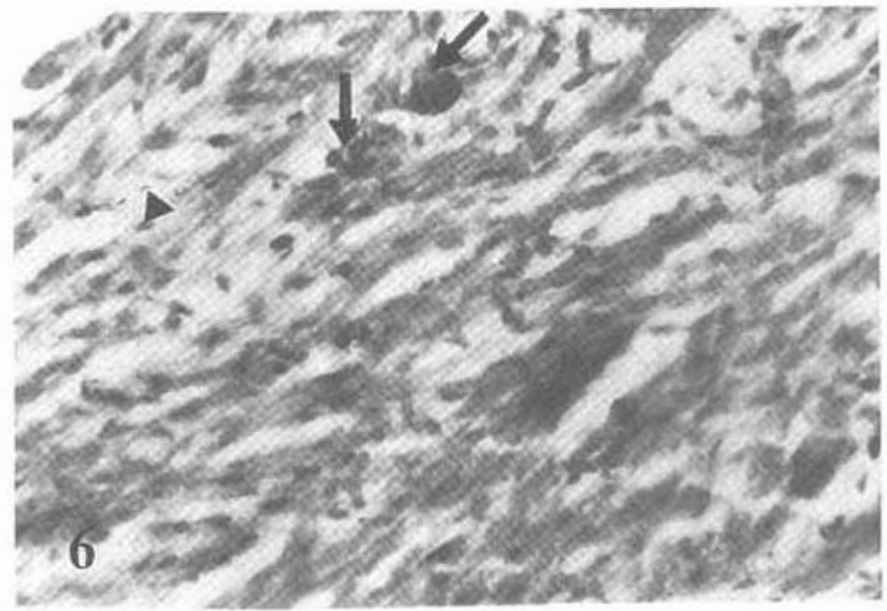

Fig. (6) : A photomicrograph of the cardiac muscle of chick embryo of group I showing partial separation of the adjacent cardiac muscle fibers ( ). Notice the eosinophilic patches $(\uparrow)$.

(Hx. \& E.; x 400)

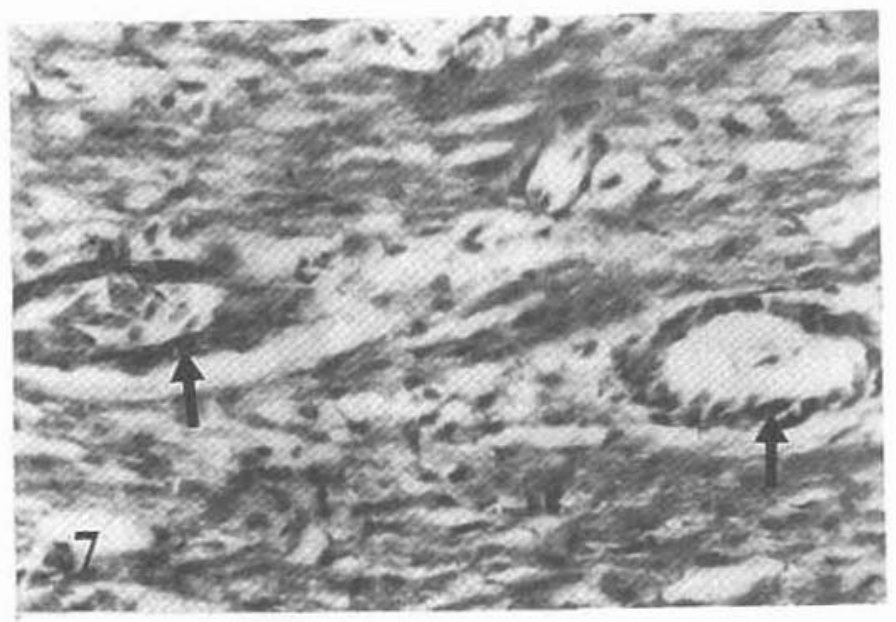

Fig. (7) : A photomicrograph of the cardiac muscle of chick embryo of group I showing mononuclear cellular infiltration $(\uparrow)$.

(Hx. \& E.; x 400) 


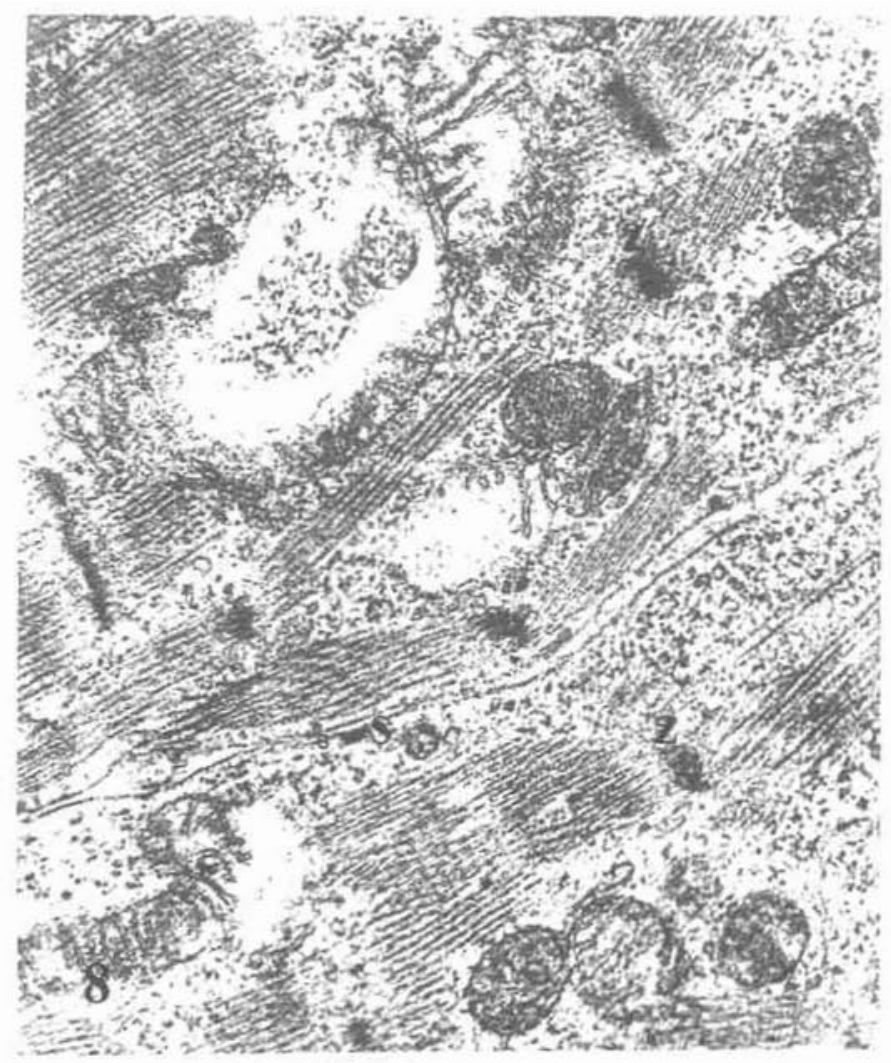

Fig. (8) : An electromicrograph of the cardiac muscle of chick embryo of group 1 showing blurred distorted $\mathrm{Z}$ lines $(\mathrm{z})$. Notice the intact sarcolemmal membrane (s).

(Uranyl acetate \& lead citrate; $x$ 22.000) 


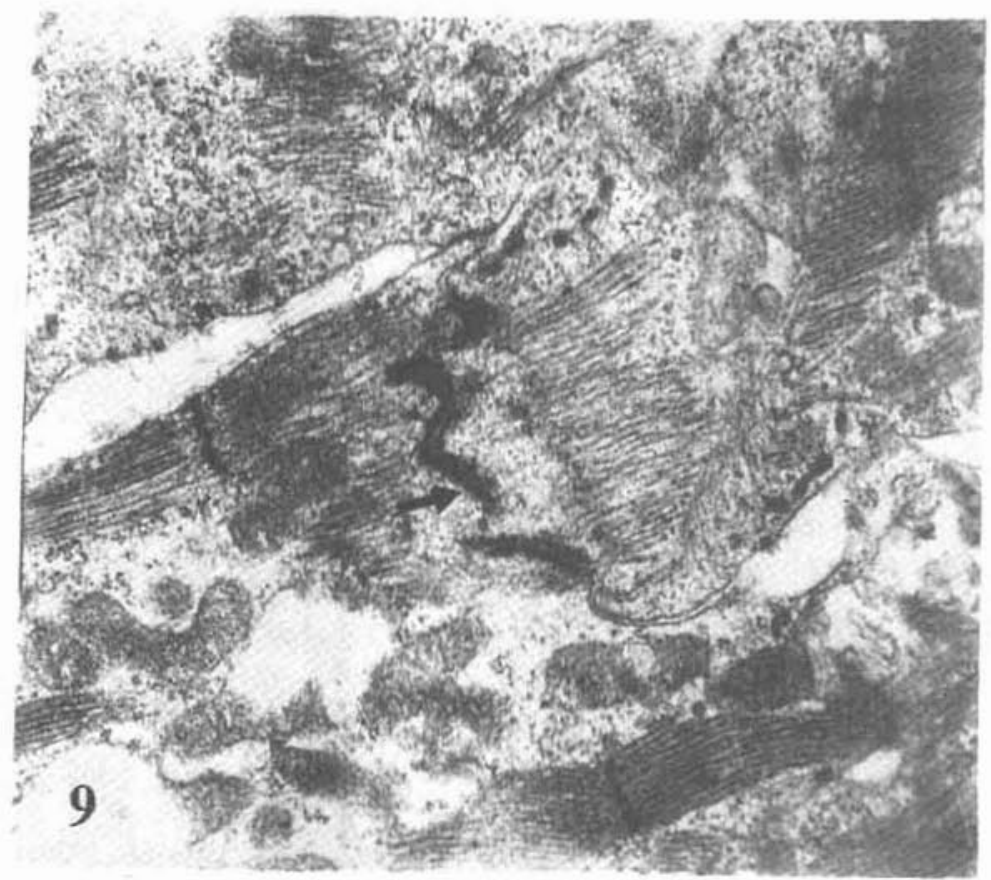

Fig. (9) : An electromicrograph of the cardiac muscle of chick embryo of group I showing intact intercalated disc $(\uparrow)$.

(Uranyl acetate \& lead citrate; $\mathrm{x} 18.000$ ) 


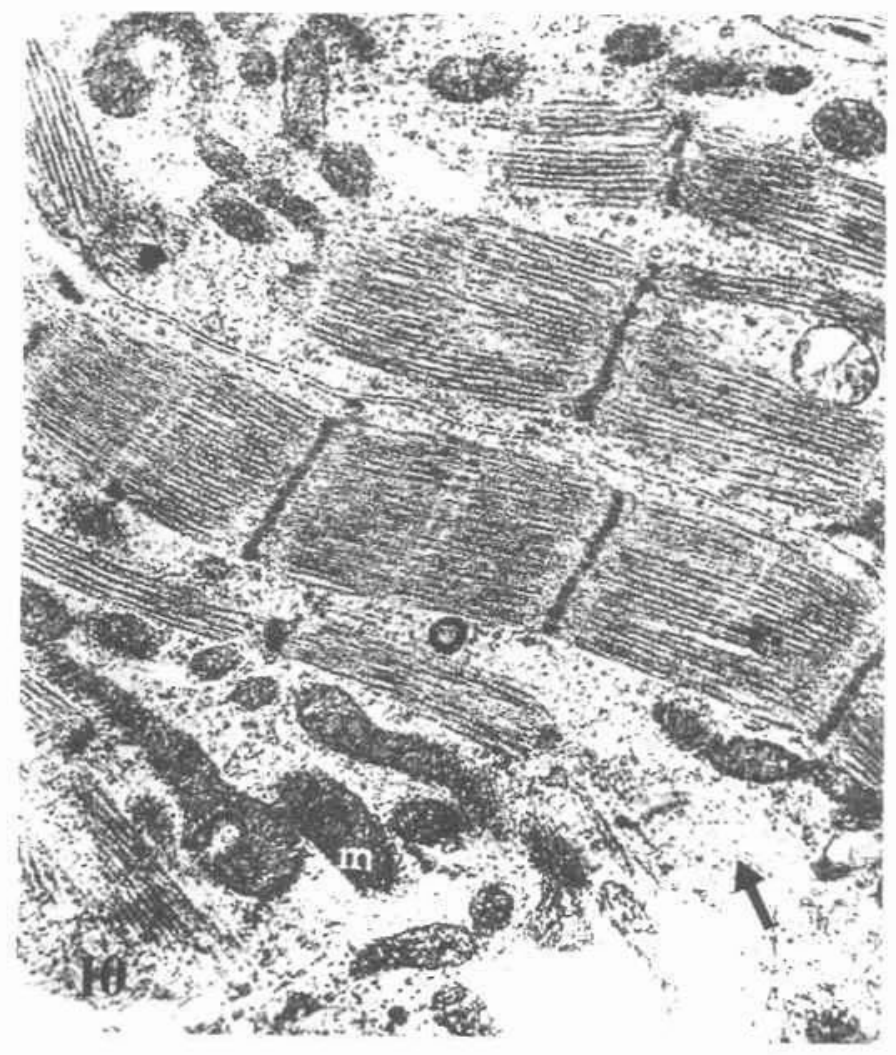

Fig. (10) : An electromicrograph of the cardtat mus Ie of chick embryo of group I showing areas of loss of striations $(\uparrow)$ and the dinse pleomorphic mitochondria $(\mathrm{m})$.

(Uranyl acetate \& lead citratc; $x$ 17.000) 


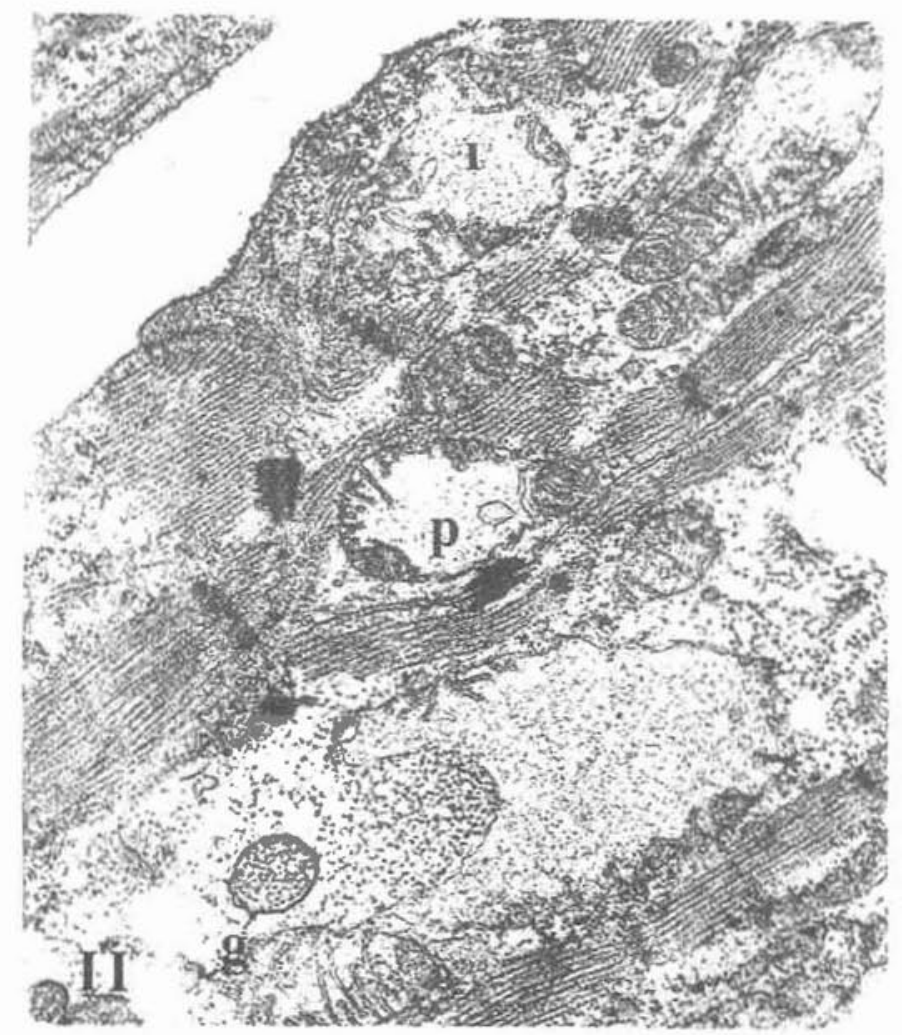

Fig. (11) : An electromicrograph of the cardiac muscle of chick embryo of group I showing mitochondria with partial loss of cristea $(p)$ or completes loss (1). Notice the glycogen roseltes (g).

(Uranyl acetate \& lead citrate; $x$ 17.000) 


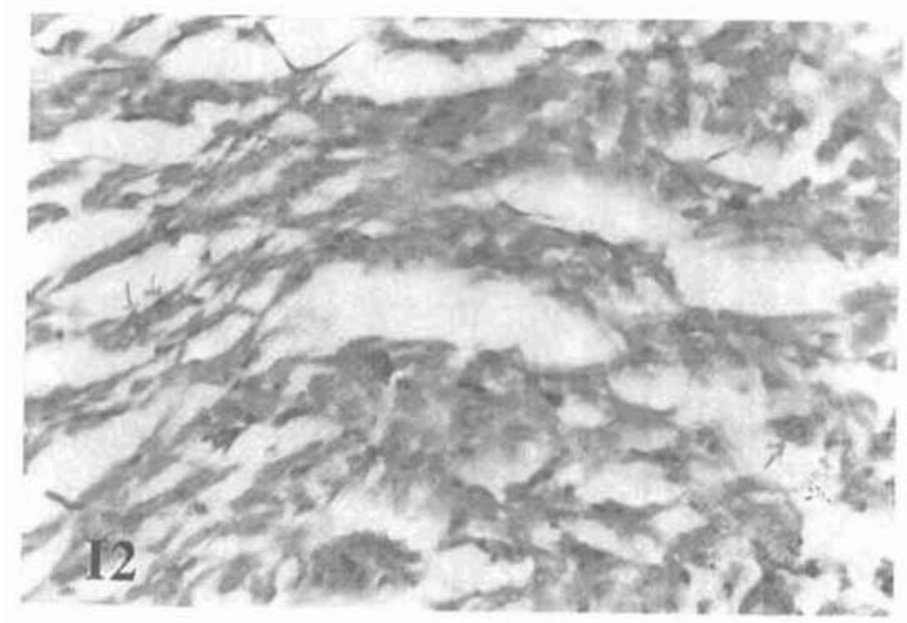

Fig. (12) : A photomicrograph of the cardiac muscle of chick embryo of group II showing wide separation of cardiac muscle fibers.

(Hx. \& E.: $x$ 400)

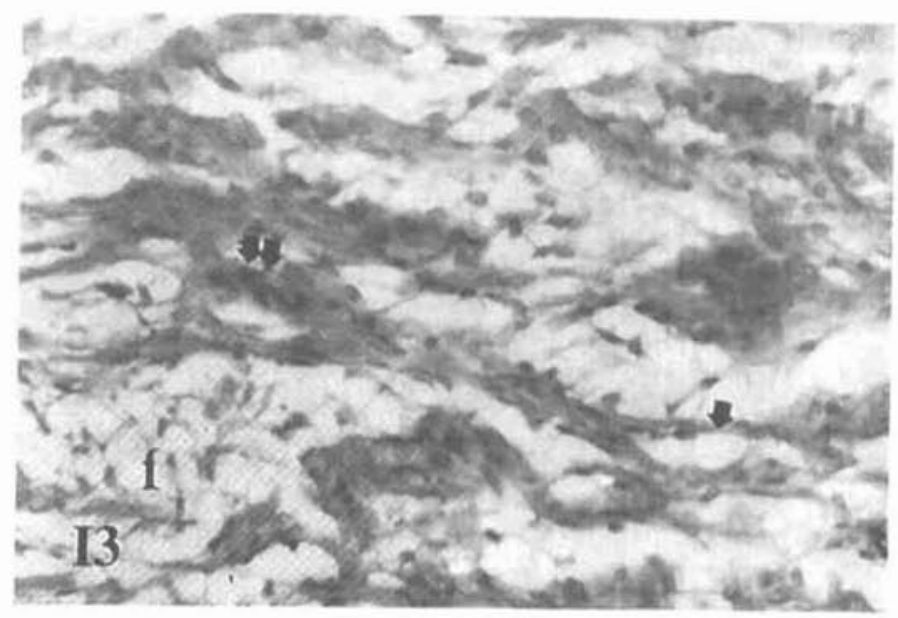

Fig. (13) : A photonicrograph of the cardiac muscie of chick embryo of group II showing marked thinning $(\uparrow)$ of the cardiac muscle fibers and extreme clumping with pyknotic nuclei ( $\uparrow$ ). Note the fat cells (f).

(Hx. \& E.; x 400) 


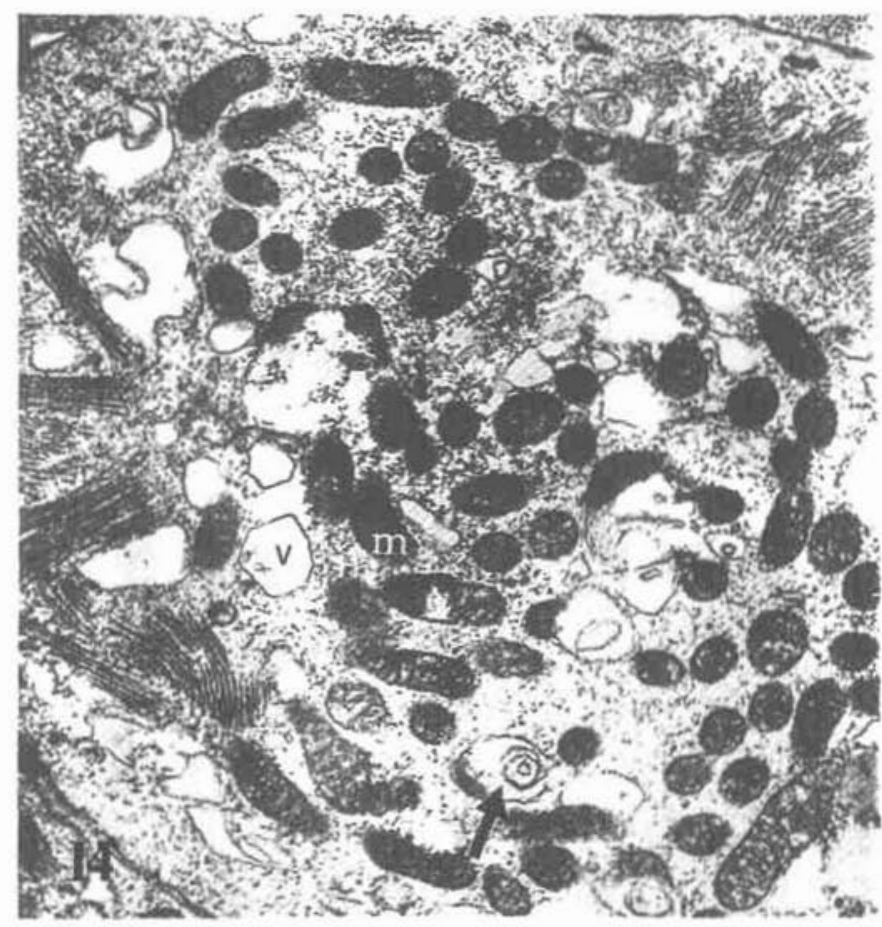

Fig. (14) : An clectromicrograph of the cardiac muscle of chick embryo of group II showing wide areas of loss of striations. Notice the dense mitochondria $(\mathrm{m})$, vacuoles (v) and myelin-like figures $(T)$.

(Uranyl acetate \& lead citrate; x 13.000) 


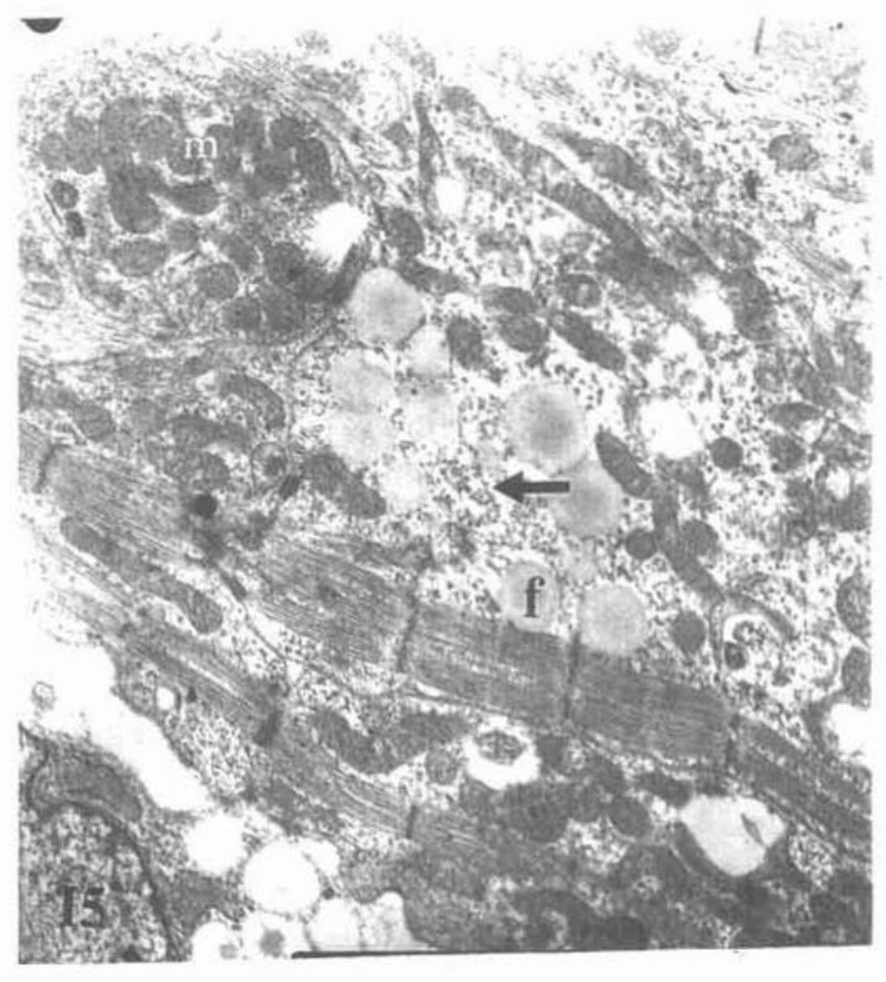

Fig. (15) : An electromicrograph of the cardiac muscle of chick embryo of group II showing areas of loss of striations ( $\uparrow$ ) infiltrated by fat droplets ( $f$ ) and aggregates of mitochondria (m).

(Uranyl acetate \& lead citrate; $x$ 18.000) 


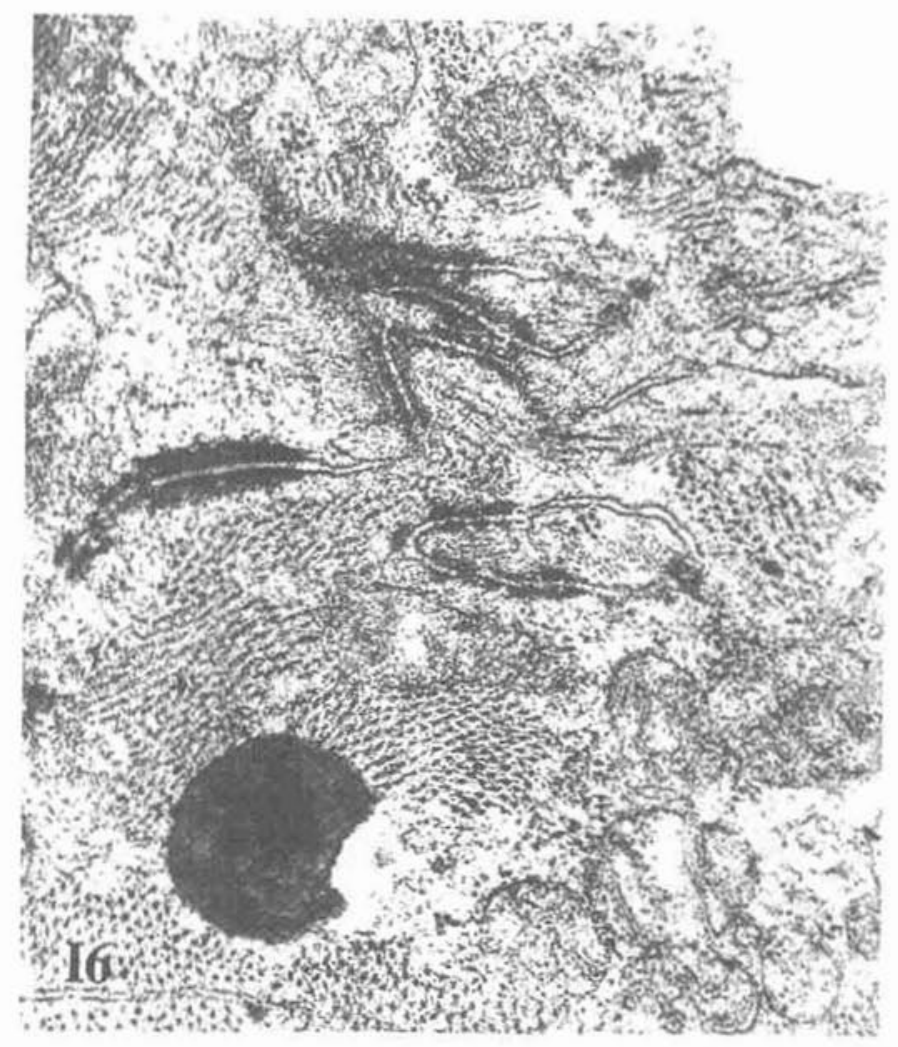

Fig. (16) : An electromicrograph of the cardiac muscle of chick embryo of group II showing marked folding of the sarcolemmal membrane (s).

(Uranyl acetate \& lead citrate; $x$ 28.000) 


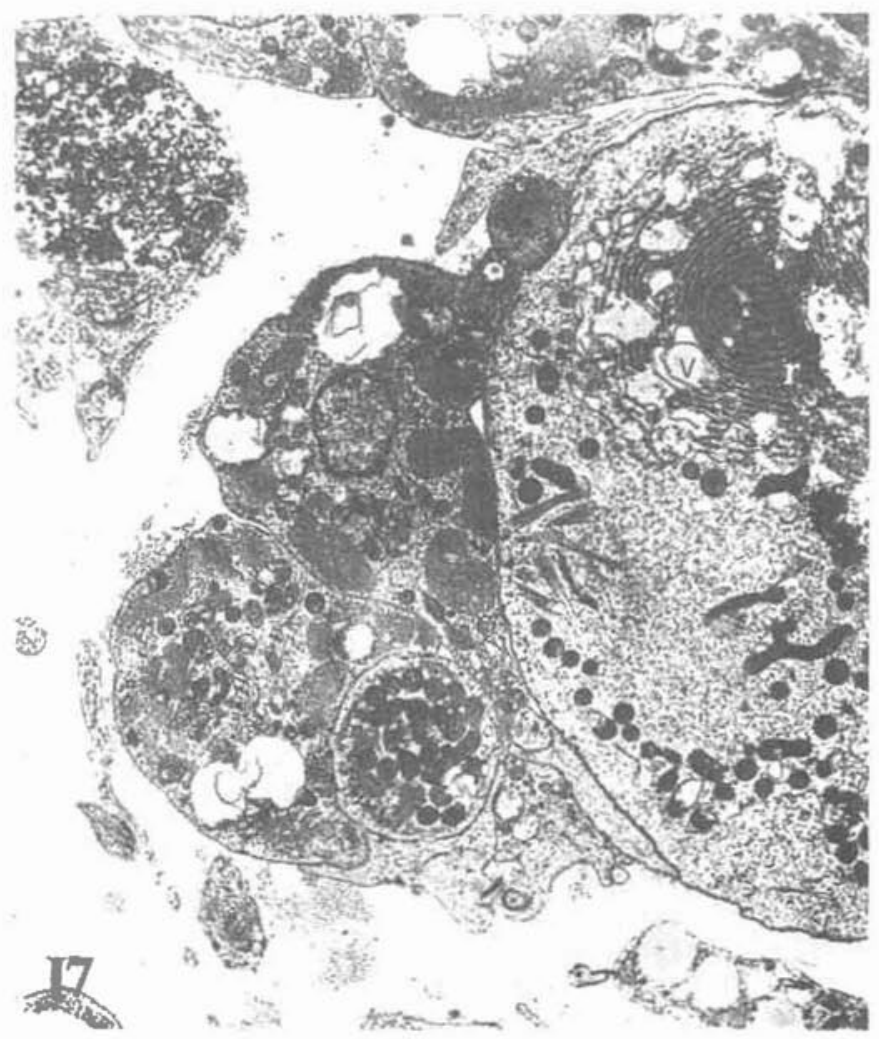

Fig. (17) : An electromicrograph of the cardiac muscle of chick embryo of group II showing proliferation of sarcoplasmic reticulum (r). Notice the interposed vacuoles $(v)$.

(Uranyl acetate \& lead citrate; $x 6000$ ) 


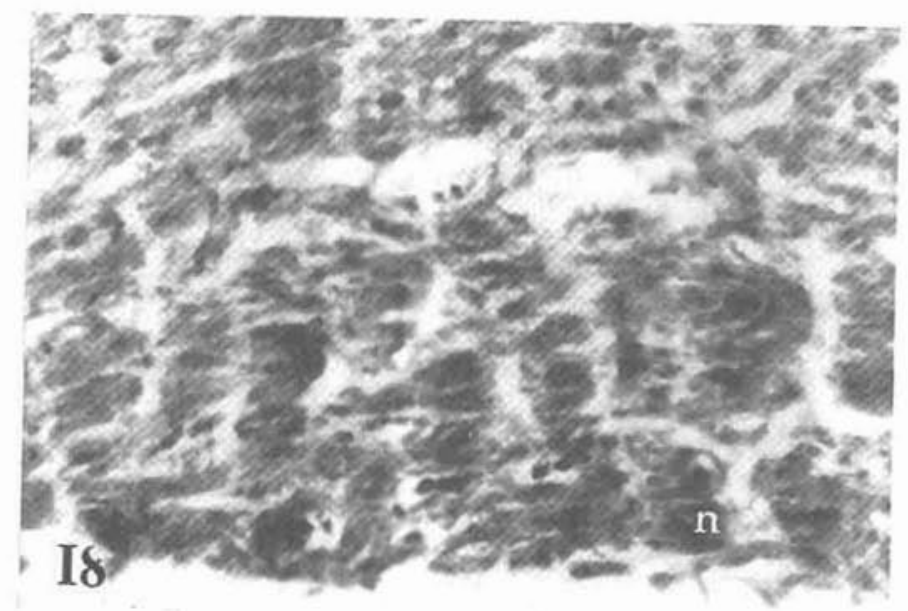
Fig. (18) : A photomicrograph of cardiac muscle of chick embryo of group III.
Notice basophilic nuclei (n).

(Hx. \& E.; x 400)

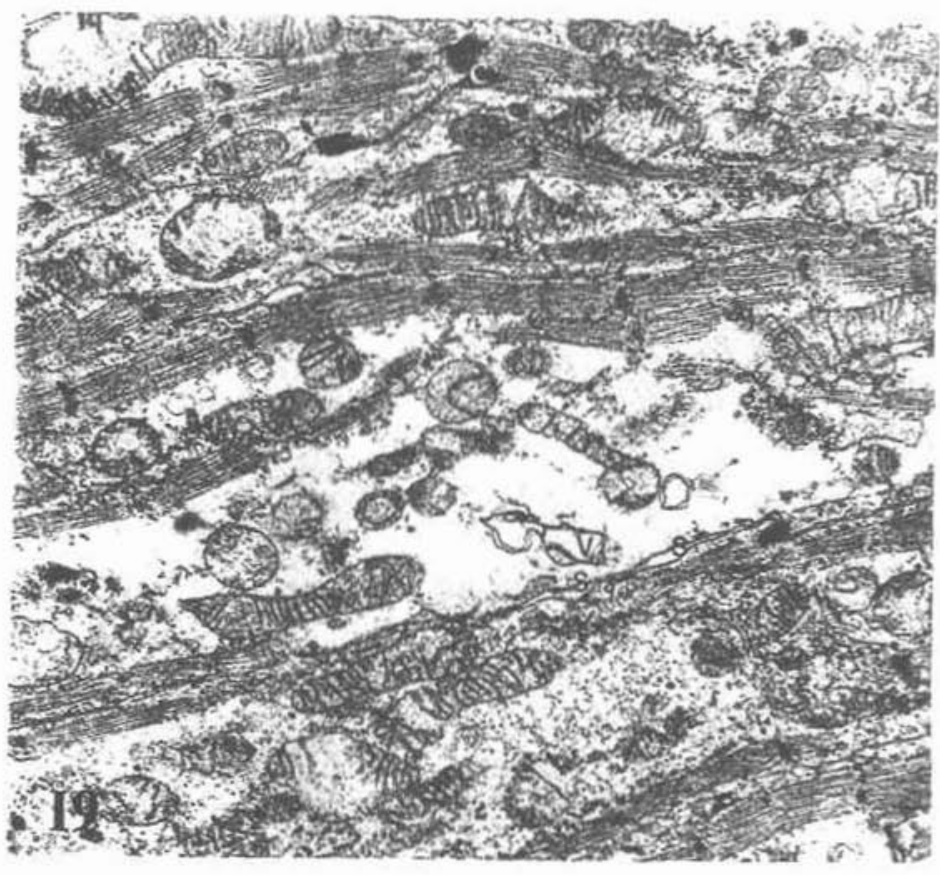

Fig. (19) : An electromicrograph of the cardiac muscle of chick enbryo of group III showing intact intercalated discs (c) and sarcolemmal membrane (s). Note the areas with loss of striations and bizarre vacuoles (v).

(Uranyl acetate \& lead citrate; x 10.000) 


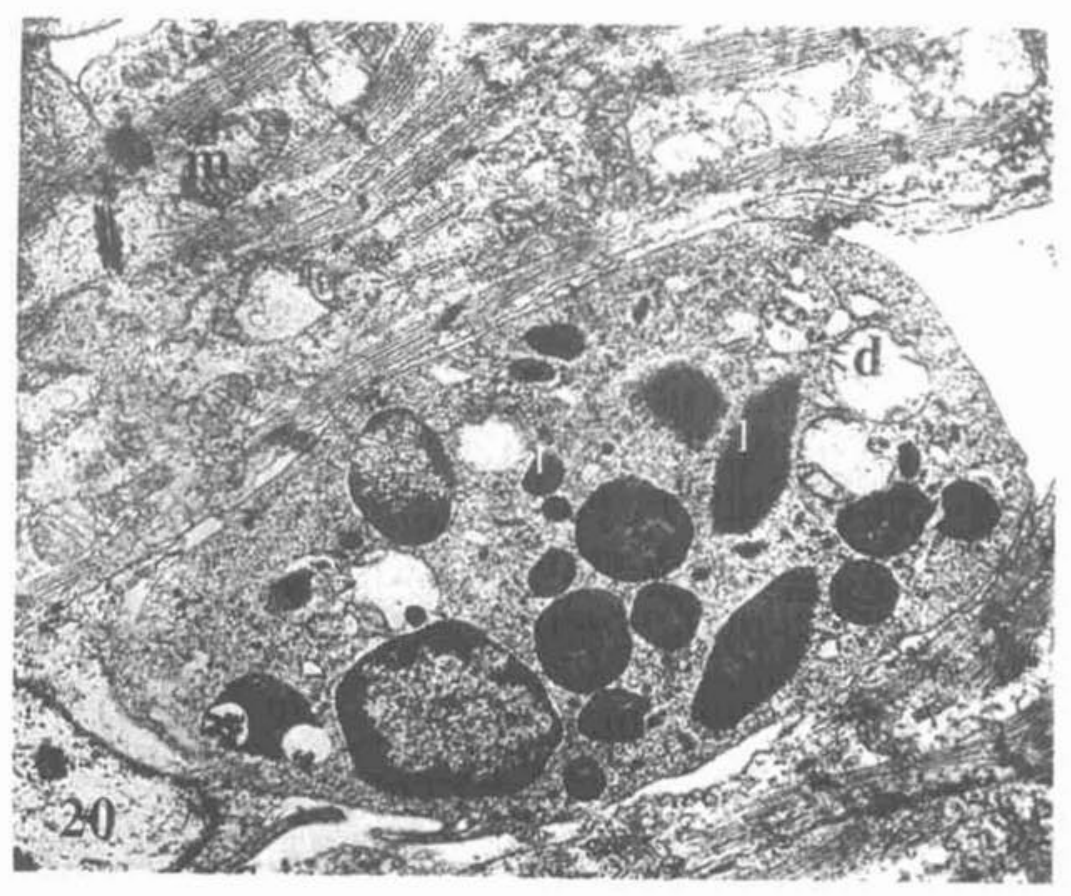

Fig. (20) : An electromicrograph of the cardiac muscle of chick embryo of group III showing large macrophage with dense lysosomes (1) and degenerated mitochondria (d). Note the mitochondria with partial loss of cristea (m).

(Uranyl acetate \& lead citrate; $x$ 10.000) 


\section{DISCUSSION}

The present study illustrated that caffeine is a rather cardiotoxic compound, that caused dose-dependent structural changes in the myocardium of chick embryos. On aministration of a total dose of $0.75 \mathrm{mg}$ divided into three doses, the myocardium showed few focal areas with partial separation of the adjacent cardiac muscle fibers. Moreover, eosinopholic homogeneously-stained patches with adherent nuclei and areas of mononuclear cellular infiltration were encountered in the myocardium.

Similar eosinopholic patches and cellular infiltration were noticed in the cardiac muscle of Sprague Dawely rats one hour following intake of LD 50 of different cardiotoxic compounds, i.e., isoprotemol, hydralazine, cyclophosphamide and adri-

- amycin. However, with these compounds the patches were numerous, interposed allover the myocardium and involved even the papillary muscle (Kemi et al., 1996).

On administration of a total dose of $1.5 \mathrm{mg}$ of caffeine divided into three doses, the cardiac muscle showed marked separation of the adjacent cardiac muscle fibers. Separation and dilatation in the intercellular spaces was reported previously in the literature following administration of caffeine. It was noticed near the basement membrane of the nonpigmented ciliary epithelium of the eye, within fifteen minutes after caffeine intake (Kurata et al., 1997).

In the present study, the myofibril degenerative changes were dose dependent. With a dose $0.75 \mathrm{mg}$ of caffeine, the myofibrils maintained an intact sarcolemmal membrane, and the cross striations were preserved. However, some Z-line were blurred and distorted. Occasionally, few small localized areas of loss of striations were observed. The intact myofibrils with slightly blurred Z-lines were described as contraction damage (Daniels and Duncan, 1993). On the other hand, with high doses of caffeine, the cardiac muscle exhibited marked disintegration and dissolution of the myofibrils resulting in wide areas of loss of striations and loss of normal pattern of sarcomeres. The wide interrupted areas were infiltrated by irregular multiple vacuoles, myelin-like figures and dense mitochondria. Other areas of loss of striations were infiltrated by fat droplets and aggregates of dense mitochondria. The disintegration and dissolution of myofibrils with loss of striations were described as a relaxation damage (Daniels and Duncan, 1993).

Fragmentation, loss of striations and contraction band formation are commonly induced by most of the cardiotoxic compounds including cyclophosphamide, isoproternol and adriamycin (Kemi et al., 1996). Moreover, myofilaments suffered also sevcre damage and disruption after administration of hypochlorus acid (Miller and 
MacFarlane, 1995). It was suggested that the structural changes in myofilaments were associated with myocyte dysfunction and could lead to ischaemic changes (Miller and MacFarlane, 1995).

In the presentg study, the ultrastructural examination further clarified that the mitochondria, in particular, displayed various changes. Some mitochondria were swollen and suffered partial or complete loss of mitochondrial cristea, others were dense, pleomorphic in shape and usually formed aggregates which infiltrated the areas with lost striations. The mitochondrial changes were observed with both doses used in the present stuy. However, with high doses of caffeine, the present work illustrated, in addition, striking proliferation of the sarcoplasmic reticulum showing finger-print appearance with few interposed vacuoles.

The caffeine-produced ultrastructural changes in the myofibrils, mitochondria and sarcoplasmic reticulum were similar to that seen after calcium release. Caffeine is believed to act by releasing calcium from intercellular sites like the sarcoplasmic reticulum and mitochondria respectively, raising the calcium levels and so triggering the ultrastructural damage of the myofibrils and the mitochondrial changes. These changes are qualitatively similar and typical to those seen after calcium-induced damage in muscle cells (Duncan and Shamsadeen, 1991; Duncan, 1992).

The release of calcium from sarcoplasmic reticulum following caffeine administration is a rather complex process. Low doses of caffeine in ventricular myocytes have been hypothesized to cause transient activation of the sarcoplasmic reticulum upon application and transient depression of the sarcoplasmic reticulum upon removal. As the concentration of caffeine increased, the release of luminal calcium and the activation of the sarcoplasmic reticulum was more evident (Lukyanenko et al., 2001).

The close association between calcium release and caffeine concentration could explain the marked proliferation of the sarcoplasmic reticulum encountered in the present study with high doses and the variation in the degenerative changes noticed with the different doses of caffeine used. Recently, it is believed that the effects of caffeine on the release of calcium from the sarcoplasmic reticulum is accompanied also by a dose-dependent sodium and calcium exchange which represents an additional element of complexity in caffeine action on the cardiac muscle (Leoty et al., 2001).

The present study demonstrated that high doses of caficipe were associated with further degenerative changes. The sarcolemmel membrane was indistinct and showed extreme folding. The structural changes in the sarcolemmal membrane 
increase the susceptibility of myofibrils to mechanical injury and predispose to subsequent massive myocardial damage (Harding and Duncan, 1996). The damaged sarcolemmal membrane enhances the release of cytosolic proteins mainly creatinc kinase, and these proteins represent another major damage pathway of caffeine (Harding and Duncan, 1996).

In the present work, administration of lidocaine with high doses of caffeine restored the sarcolemmal membrane. Lidocaine completely inhibits the relcase of creatine kinase probably via the membrane stabilizing elfect of this local anaesthetic (Harding and Duncan, 1996).

Although the sarcolemmal membrane was intact and preserved following lidocine application, yet the cardiac muscle exhibited areas of loss of striations and structural changes were still encountered in the mitochondria. Moreover, large macrophages were interposed tetween myofibrils containing degenerated mitochondria and prominent lysosomes. These changes are characteristic of cardiac muscle that have experienced a rise in calcium levels. It could be emphasized that caffeine caused probably a rise in calcium levels that initiated damage of the myofibrils inspite of the stabilizing effect of lidocaine on the sarclemmal membrane and the substantial protection against cytosolic proteins and creatine kinase release (Harding and Duncan, 1996).

It could be concluded that caffeine exerted its effects via different damage pathways that acted independently and separatcly. Although the release of calcium and cytosolic proteins seem to be the two major pathways of damage of calfeine, yet other factors may be involved in the action of caffeinc. Dysomorphogenesis and impairment in the heart formation in new born rats of dams fed on diet rich in caffeine, was attributed to affection of superoxide dismutase enzyme (Rossowska and Nakamoto, 1994). On the other hand, it was postulated that effects of caffeine on the cardiac muscle were not mediated via the calcium release, but via another mechanism independent of calcium and involved direct action of caffeine on the actin cross bridge interactions (Powers and Solara, 1995).

In conclusion, the present study clarified that caffeine could be considered as a cardiotoxic compound. It caused few structural changes in low doses, but in high doses it caused severe ultrastructural changes. The action of caffeine is mediated probably via the release of calcium and cytosolic proteins. Lidocaine can stabilize the sarcolemmal membrane and partly protect the myocardium against the damaging effects of caffeine. 


\section{SUMMARY}

The present study investigated the effects of caffeine on the cardiac muscle of chick embryos and whether these effects were ameliorated by lidocaine. Ninety fertilized leghorn eggs werc subdivided into three groups. The first group of eggs were instilled with a total dose $0.75 \mathrm{mg}$ of caffeinc divided into three successive doses on the $5^{\text {th }}, 10^{\text {th }}$ and $15^{\text {th }}$ days of incubation. In this group, the cardiac muscle showed areas of partial separation of the adjacent muscle fibers. cosinophilic stained patches and mononuclear cellular infiltration. Ultrastructural examination revealed intact sarcolemmal membrane, intercalated discs and preserved cardiac striations. Few Zlines were blurred. The mitochondria were swollen with partial or complete loss of mitochondrial cristea. Glycogen granules formed aggregated rosettes.

The second group of eggs were instilled with a total dose of $1.5 \mathrm{gm}$ of caffeine divided into three successive doses on the $5^{\text {th }}, 10^{\text {th }}$ and $15^{\text {th }}$ days of incubation. In this group, the cardiac muscle showed distorted arrangement and wide separation of the adjacent cardiac muscle fibers. Fatty cellular infiltration and pyknotic nuclei were observed. Ultrastructural examination revealed loss of regular pattern of striation, irregular vacuoles, myelin-like figures and dense mitochondria. The sarcolemmal membrane was highly folded and the sarcoplasmic reticulum showed marked proliferation.

The third group of eggs were instilled with a total dose of caffeine $1.5 \mathrm{mg}$ simulantaneously with $0.2 \mathrm{ml}$ lidocaine $2 \%$ divided into three successive doses on the $5^{\text {th }}, 10^{\text {th }}$ and $15^{\text {th }}$ days of incubation. The cardiac muscle showed a preserved architecture and dense basophilic adherent nuclei. Ultrastructural examination revealed intact sarcolemmal membrane and intercalated discs. Some areas showed loss of striations with infiltration by bizarre vacuoles. Partial loss of mitochondrial cristea, large macrophages containing prominent lysosomes and degenerated mitochondria were encountered.

The results were discussed, and it was concluded that caffeine is rather cardiotoxic especially in high doses. Lidocaine stabilized the sarcolemmal membrane and provided partial protection. 


\section{REFERENCES}

1. Cavagna, M.; O'Donnel, J.M.; Submilla, G. and Klein, M.G. (2000) : Exogenous $\mathrm{Ca}^{+2}$ ATPase isoform effects on $\mathrm{Ca}^{+2}$ transients of embryonic chicken and neonatal cardiac myocytes. J. Physiol., 528 (1) : 153 - 163.

2. Daniels, S. and Duncan, G.J. (1993) : Cellular damage in the rat heart caused by caffeine or Dinitrophenol. Comp. Biochem. Physiol,, 105 (2) : 225 - 229.

3. Duncan, C.J. (1992) : Pathphysiology of reperfusion injury in muscle cells : In pathophysiology of Reperfusion injury. as, D.A. (ed.), CRC Press Inc. Boca Raton, U.S.A., pp. $395-415$.

4. Duncan, G.J. and Shamsadeen, N. (1991) : Ultrastructural changes in mitochondria during rapid damage triggered by calcium : In calcium oxygen radicals and cellular damage. Duncan, G.J. (ed.), Cambridge University Press, U.K., pp. 149 164.

5. Fredholm, B.; Battig, K.S.; Holmen, D.; Nehlig, A. and Zvartau, E. (1999) : Actions of caffeine in the brain with special reference to factors that contribute to its wide spread use. Pharm. Rev., 51 (1) : 83 - 133.

6. Guillet, R. and Dunham, L. (1995) : Neonatal caffeine exposure and seizure susceptiblity in adult rats. Epilepsia, 36 (8) : 743 - 749.

7. Harding, R.J. and Duncan, G.J. (1996) : Protective effect of lidocaine on cell damage in the perfused rat heart. Path. Biol., 64 (4) : 209 - 216.

8. Hughes, J.R.; Oliveto, A.H,; Liguori, A.; Carpenter, J. and Howard, T. (1998): Endorsement of D.S.M. - IV dependence criteria among caffeine users. Drug Alcohol Depend., 52 : 99 - 107.

9. Iwase, T.; Arishima, K.; Ohyama, N.; Inazawa, K.; Iwase, Y.; Iukeda, Y.; Shirai, M.; Yamamoto, M.; Soniya, H. and Eguchi, Y. (1994) : In vitro study of teratogenic effects of caffeine on cultured rat embryos and embryonic cells. J. Vet. Med. Sci., 56 (3) : 619 - 621.

10. Kemi, M.; Matsumoto, H.; Nomura, Y, and Takahashi, R. (1996) : Early myocardial lesions induced by cardiotoxic compounds in Sprague Dwaley rats. J. Vet. Med. Sci., 58 (7) : 699 - 702 ,

11. Kurata, K.; Mocda, M.; Nishida, E.; Tsukuda, R.; Luzuki, T. and Toduriki, M. (1997) : Relationship between caffeine induced ocular hypertension and ultrastructure changes of non pigmented ciliary epithelial cells in rats. J. Toxicol. Sci., $22(5): 447$ - 454. 
12. Leoty, C.; Huchet-Cadio, C.; Talons, S.; Choisy, S. and Hleihel, W. (2001) : Caffeine stimulates the reverse mode of $\mathrm{Na} \mathrm{Ca}^{+2}$ exchanger in ventricular musc $\mathrm{l}$ : Acta Physiol. Scand., 172 (1): 27 - 37.

13. Lukyanenko, V.; Viatchenko, S.; Smirnov, A.; Wiesnery T.F. and Gyorke, S. (2001) : Dynamic regulation of sarcoplasmic reticulum $\mathrm{Ca}^{+2} \mathrm{cont} \cdot \cdots 1$ and release by lumenal $\mathrm{Ca}^{+2}$ sensitive leak in rat ventricular myoc yte Bioplys., 81 (2) $785-798$.

14. Matsuka, R.; Uno, R.; Tanaka, H.; Kers, C.S. and Nadai Ginard, B. (1987) : Caffeine induces cardiac and other malformations in the rat. Am. J. Mcd. Genefies Suppl., (3) : 433 - 443.

15. Miller, M.S.; Friedman, W.F. and Wetzel, G.T. (1997) : Caffeine induced contractions in developing rabbit heart. Pediat. Res., 42 (3) : 287 - 292.

16. Miller, D.J. and MacFarlane, N.G. (1995) : Intracellular effects of free radicals and reactive oxygen species in cardiac muscle. J. Human Hyperten., 9 (6) : 465 473.

17. Miller, R.C.; Watson, W.J.; Hackrey, A.C. and Seeds, J.W. (1994) : Acute maternal and fetal cardiovascular effects of caffeine ingestion Am. J. Perinatal., $11(2): 132$ - 136.

18. Person, M. (1983) : The role of movments in the development of stural and diarthrodial joints tested by long term paralysis of chick embryos. J. Anat., 137 (3) : $591-599$.

19. Powers, F.M. and Solara, R.J. (1995) : Caffeine altrers cardiac myofilament activity and regulation independently of $\mathrm{Ca}^{+}$binding to troponin $\mathrm{C}$. Am J. Physiol., 268 (6) : C1348 - C1353.

20. Rossowska, M.D. and Nakamoto, T. (1994) : Effects of chronic caffeine feeding on activities of oxygen free radicals defense enzymes in the growing rat heart and liver. Experientia, 50 (5) : 465 - 468.

21. Shai-Linin, M.D.; Schoenbarm, S.G.; Manson, R.R.; Rosner, B.; Stubblefield, P.G. and Ryan, K.J. (1982): No association between coffee consumption and adverse outcomes of pregnancy. N. Eng. J. Med., $306: 141$ - 145.

22. Xu, L. and Meissner, G. (1998): Regulation of cardiac muscle $\mathrm{Ca}^{+2}$ release channel by sarcoplasmic reticulum lumenal $\mathrm{Ca}^{+2}$ Biophys. $J_{.,} 75$ (5): 2302 2312. 


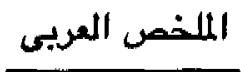

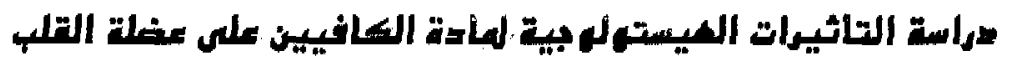

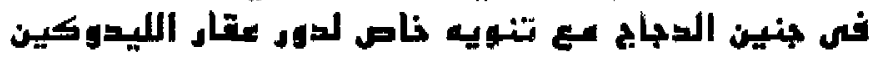

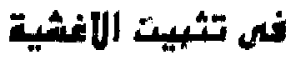

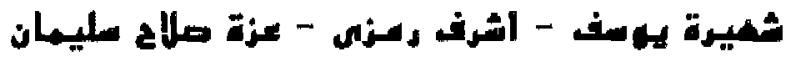 \\ تسم التشريح - كلية الطب - جامعة عين ثمس رئر}

القد أهرى هذا البحث لدراسة تأثير مادة الكافيين على عضلة القلب لجنين الدجاج

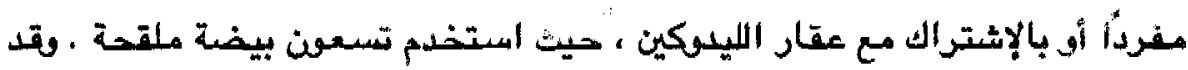

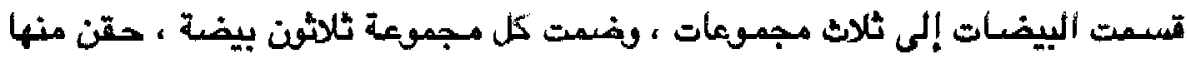
خمسة ومشرلن بالكافيين ، بينما استخدمت الخمس بيضات الأخري كعينات خابطة

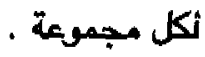

ققد ثم حقن المجموعة الأولى من البيض بجرعة متوسطة من عقار الكافيين هيث أظهرت عضلة التلب لأجنة الدجاجات الخاصة بهذه المجموعة مسياحات من الإنفصال الجزئى لألياف عضلة القلب المتجاورة ، كما طهرت بقع صبغية حمراء متجانسية اللون

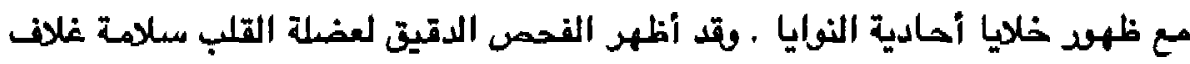

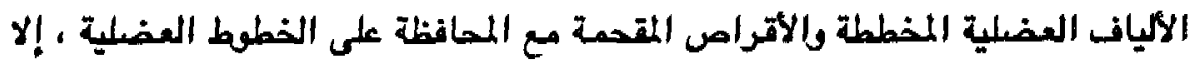

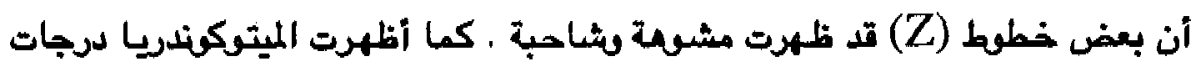

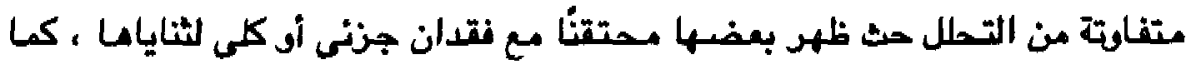

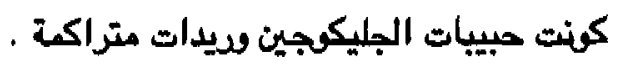

كما تم حقن المجموعة الثانية بالجرعة الاكبر من الكافيين حيث أظهرت عضلة

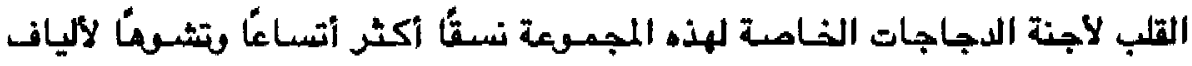
عضلة القلب كما ظلهرت ترسبات دمنية ونوايا متغلظة . 
كلقد أظهر الفحص الدقيق لعضلة القلب فقدان الثكل النمطي للخطوط العضلية

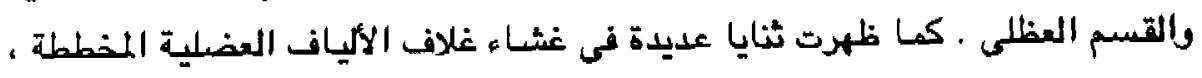

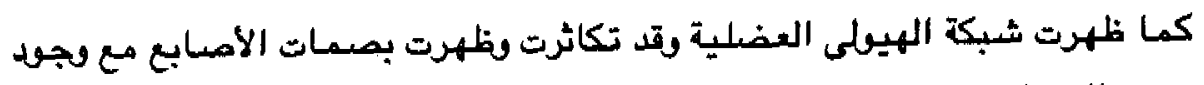

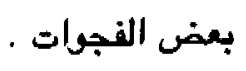

كما تم حقن المجموعة الثالثة بالجرعة الاكبر من الكافيين بالإضـافة إلى عقار

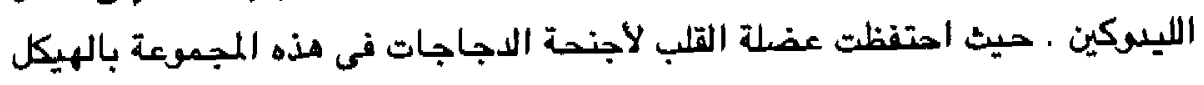

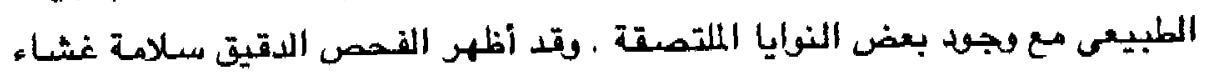

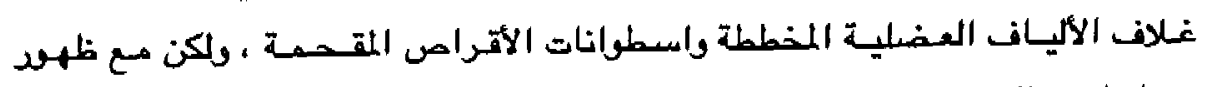

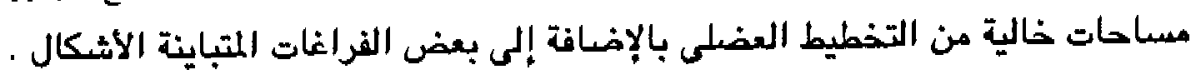

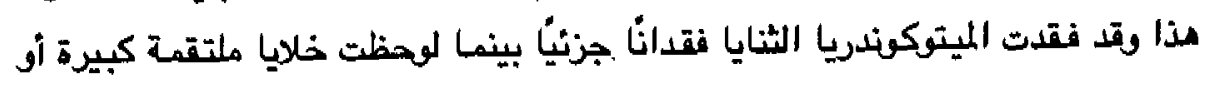

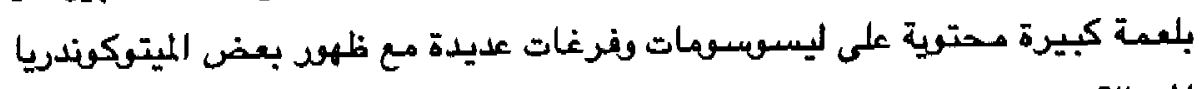
المتحللة .

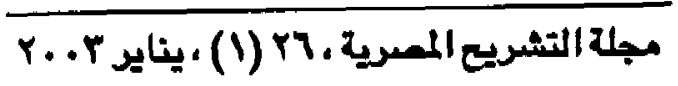

